\title{
Impact of Gerard van Swieten on the Development of Austrian Medicine Throughout the $18^{\text {th }}$ Century
}

\author{
Boro Bronza
}

\begin{abstract}
Arrival of Doctor Gerard van Swieten in Vienna, in 1745, as new personal physician of the Holy Roman Empress Maria Theresa, was starting point of a huge wave of transformation in the scope of Austrian medicine. Scientific and methodological experience which doctor from Leiden brought in Habsburg capital was so overwhelming that whole structure of medical science was shattered and reconstructed in a much more efficient way. Impact of Van Swieten was a splendid example of dominance of scientific method in the Netherlands, where modern European science gained more ground than anywhere else during the classical era of baroque, throughout the $17^{\text {th }}$ and first half of the $18^{\text {th }}$ century. On the other hand, internal reforms and transformation of Austria, from the mid-18 ${ }^{\text {th }}$ century, helped a lot in the process of successful reception of new structural ideas. Through this kind of merging, inside of only several decades, Vienna managed to grow into one of leading centres of medical science in Europe and the world.
\end{abstract}

Keywords: The Netherlands; Medicine; Leiden; Gerard van Swieten; Austria; Vienna.
(1) Department of History, Faculty of Philosophy, University of Banja Luka, the Republic of Srpska, Bosnia and Herzegovina.

Correspondence:

BORO BRONZA

E: boro.bronza@ff.unibl.org

\section{ARTICLE INFO}

Received: 5 December 2020 Accepted: 13 December 2020

\section{Consequences of "the Dutch Golden Age"}

The complex political processes of the second half of the $16^{\text {th }}$ century at the plains of the Netherlands, imbued with aspects of the consequences of the Reformation after a long war for liberation from Spanish domination (1568-1648), resulted in the emergence and rapid development of the United Provinces of the Netherlands (officially called the Republic of the Seven United Netherlands and usually called the Dutch Republic). Politically and economically, the most important of seven provinces was Holland, and because of that the whole state system was usually set in the same manner as in the strongest province. ${ }^{1}$ Almost the entire $17^{\text {th }}$ century represented the golden age of the
Dutch state, because in that period it developed into the most economically prosperous and socially sophisticated European region. Such social and economic development was accompanied by adequate development in the field of science and one of the most developed scientific fields was medicine. $^{2}$

Already during the $17^{\text {th }}$ century, the Dutch medical school was established on new scientific empirical bases, and increasingly distanced itself from the European medieval medical heritage domiated at that time still mainly by alchemy. Many famous Dutch masters of painting of that

Copyright $\odot 2021$ Bronza. This is an open access article distributed under the Creative Commons Attribution License (CC BY), which permits unrestricted use, distribution, and reproduction in any medium, provided the original work is properly cited. This article should be cited as follows: Bronza B. Impact of Gerard van Swieten on the development of Austrian medicine throughout the $18^{\text {th }}$ century. Scr Med 2021 Mar;52(1):59-68. 


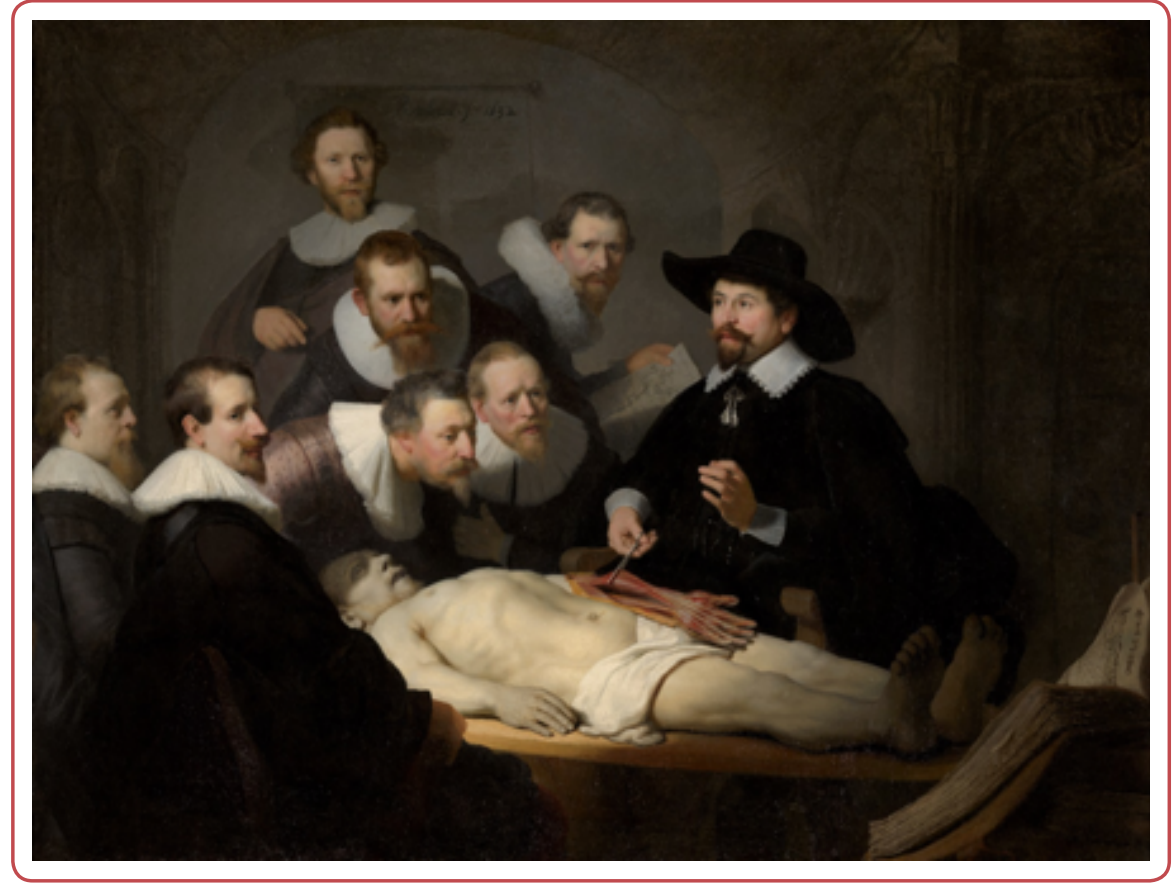

Figure 1: Rembrandt van Rijn -The Anatomy Lesson of Dr Nicolaes Tulp (1632) time displayed scenes on their canvases, that witnessed the progressiveness of medical science in the Dutch provinces. Well-known examples of such an approach were, among others, paintings by Rembrandt van Rijn (1606-1669) "The Anatomy Lesson of Dr Nicolaes Tulp" (De anatomische les van Dr. Nicolaes Tulp), in 1632 (Figure 1) and "The Anatomy Lesson of Dr Deijman" (De anatomische les van Dr. Deijman) in 1656.

With the intellectual and cultural surrounding enriched by the presence of persons like René Descartes (1596-1650), Christiaan Huygens (1629-1695) or Baruch Spinoza (1632-1677) and with genius pioneering inventions of Antoni van Leeuwenhoek (1632-1723) in the field of microscopy and his further revolutionary approach in the establishment of microbiology as new branch of science, scene was completely set in the Netherlands for another wave of breakthrough in medicine at the turn of $18^{\text {th }}$ century.

Amsterdam was unquestionable centre of oeconomic life and trade of all Seven Provinces of the Netherlands and a leading world port, which was especially underlined with the founding of huge colonial corporations the Dutch East India Company (Veerenigde Oostindische Compagnie - VOC), since 1602, and the Dutch West India Company (Geoctrooieerde Westindische Compagnie - GWC), since 1621 and first world modern stock exchange as subsequence of mentioned companies. ${ }^{3}$ On the other hand, The Hague, in South Holland, was po- litical centre of Provinces, with the permanent seat of the "stadtholder" and government there since $1588 .{ }^{1}$ At the same time, City of Leiden, geographically situated between Amsterdam and The Hague, became a crucial scientific centre, especially with the role of the first university in Dutch Republic opened there in 1575.

University of Leiden grew pretty fast into one of the leading institutions of European science, mainly because of special conditions of intellectual tolerance that ruled in the Netherlands, and in Holland more than anywhere else. Throughout the $17^{\text {th }}$ century University of Leiden managed to build excellent reputation at the continent and was starting point for careers of all already mentioned carriers of "the Dutch Golden Age". During this time, Leiden also became the home for leading persons in the field of medical science.

One of superb products of medical science developed at University of Leiden was Herman Boerhaave (1668-1738). He had a chair at the Institute of Medicine in Leiden since 1701. Boerhave was leading European physician of era at the turn of the $18^{\text {th }}$ century. Besides of that he was outstanding botanist and chemist, as connections and borders between medicine, biology and chemistry were still blurry at that time. Famous doctor from Leiden is often regarded as the father of clinical teaching and inventor of the quantitative approach into medicine. Since 1714 he was appointed as rector of the leading Dutch university. 


\section{Van Swieten between Leiden and Vienna} It was exactly in this exceptional scientific surrounding of Leiden that Gerard van Swieten was born, on 7 May 1700. He was offspring of a prominent Catholic family in Leiden. Although majority of Dutch provinces, and Holland especially, were predominantly inhabited with Reformed Protestants (Calvinists), Catholics have been mainly pretty fairly tolerated. Still, some restrictions have been in place even further, as a consequence of past times and conflicts with catholic Spain, and Van Swieten was about to learn some rough sides of those hurdles in the upcoming decades of his development in Leiden. Start of the life itself was already harsh for little Gerard, for he lost both of his parents, father Thomas (1662-1712) and mother Elisabeth (d. 1708), early in the childhood. $^{4}$

Without any sibling, growing with two friends of his late father, who were appointed as his guardians, Van Swieten made first steps in his education and managed to excel from the very start. After finishing the Latin school at the age of 12, under careful tutelage of Jesuits, he continued fast further up to the first enrolment at the Leiden University, when he was only $14 .{ }^{5}$ His first intention was to study philosophy, but later on he moved to also very famous University of Leuven, in the Austrian Netherlands (today Belgium) and because of special interest in pharmacy he developed there, he decided to pursue training at one of the leading pharmacists in Amsterdam, Laurens Tatum. After some two years in Leuven and Amsterdam he returned to Leiden, finishing his education in the field of pharmacy at the Leiden University first, and then studied medicine only. His crucial professors have been rector Herman Boerhaave himself and Bernhard Siegfried Albinus (1697-1770), prominent lecturer in Anatomy and Surgery, originally from the German city of Frankfurt on the Oder, brought to Leiden from Paris, by personal invitation from the rector Boerhaave. ${ }^{6}$ Van Swieten's studies have been crowned with obtaining of his medical doctorate in 1725 . His dissertation with the title De arteriae fabrica et efficacia in corpore humano, that concentrated on the functioning of arteries, was finished under the mentorship of Albinus, who will later also hold the position of rector at the Leiden University. ${ }^{4}$

Although Van Swieten was outstanding student throughout his complete education, he was not in a position to become professor at the Univer- sity of Leiden, because religious restrictions still prevented Catholics to gain such level at one of the leading institutions of the protestant Netherlands. Therefore, he was only granted with possibility to start a private medical practice in Leiden. ${ }^{5}$ Even that kind of activity brought him in some conflict situations with the University and sometimes even with the rector Boerhaave. Nevertheless, after his promotion he has continued to attend the Boerhaave's classes all the way until the death of this leading professor at the University in $1738 .{ }^{6}$ In this way, Van Swieten managed to gather best possible medical knowledge and his ever-broader practice enabled him even broader scope of worthy experience. Besides scientific career, Van Swieten also managed to be a successful family man. He married Maria van Coesfelt (1711-1784) in 1729 and they would have six children between 1731 and 1746. Among them was the oldest son, Gottfried van Swieten (17331809), who will later continue father's glory in the role of one of leading Austrian diplomats. ${ }^{5}$

New turn of events came for Van Swieten at beginning of the 1740's, when his medical glory in Leiden was already well-known fact around Europe. Immediately after the death of the previous personal physician of the Holy Roman Empress Maria Theresa, Joannes Baptista baron Bassand, in November 1742, Austrian diplomatic network was set in motion to find a suitable replacement. In that frame Gerard van Swieten was contacted by the Austrian ambassador in The Hague, Judas Thaddäus baron Reischach (1696-1782), with the offer to come to Vienna and to take over the role of new personal doctor in the service of the empress. ${ }^{4}$ Joannes Baptista Bassand was also former student of Boerhaave, so the choice of Van Swieten as a Catholic, was a very logical move of the Vienna Court. The offer for position of personal physician of the Empress was even combined with the role of director of the court library. ${ }^{5}$

At first, he decided to decline that splendid offer. The idea of leaving Leiden did not easily fall to Van Swieten. When, in 1744, he received another invitation from the Austrian Secretary of State, Koch, to move to a new post in Vienna, he replied with a lot of melancholy: "The past has taught me that my heart is too delicate to bear the thought of separating from my homeland, from my family and from my friends." (Het verleden heeft mij geleerd dat mijn hart te teer is om aleen al de gedachte te verdragen dat ik zou moeten scheiden van mijn vaderland, van mijn familie and van mijn vrienden.). ${ }^{4}$ 
In his approach regarding the future career Van Swieten was more and more advised by his friend from the studies in Leiden and another pupil of Boerhaave, Portugese doctor António Nunes Ribeiro Sanches (1699-1783). At that time Sanches was the personal physician of the Russian Empress Elizabeth Petrovna (ruled 1741-1762). ${ }^{7}$ Up until October 1744 Van Swieten changed his mind and accepted the Austrian offer and by May 1745 he arrived in Vienna together with the family. His earlier convictions that he, as convinced republican cannot be turned into "monarchist" have been overturned, so he made another huge step in his transformation (Van republikein tot monarchist), ${ }^{4}$ which actually was another testimony of maturity and pragmatism in his development.

\section{Wave of reforms}

During the first half of the $18^{\text {th }}$ century, Austria has made only small steps regarding the internal stabilisation and centralisation of the state power. Reign of the Habsburg Emperor Charles VI (1711-1740) was mainly filled with failures and defeats in the international arena. For Charles VI was without a male heir, his oldest daughter Maria Theresa succeeded him as Empress in 1740, as young woman of only 23 . Lack of experience in almost every aspect of leadership at the state level was very obvious in Austria, through the 1740's. That was one of key explanations why Van Swieten was granted with so much freedom to implement reforms in education from the very start.

When arrived in Vienna, Van Swieten faced the social system with much less democracy and liberty than in his homeland. Although even provinces of the Netherlands were in decline around the middle of the $18^{\text {th }}$ century in comparison with the standards of Golden Age from earlier decades, they were still far ahead of level of Habsburg hereditary lands. The shape of his personal relations with the Empress was indeed crucial for the position of Van Swieten and his maneuverable capabilities from the very start. For he was very able to secure her intensive inclination pretty fast, therefore he was granted with huge prerogatives in the scientific field. First of all, he aimed to implement huge transformation inside of the system of medical education in Austria and also to completely reform the health service.

One of the first measures was concentration on sanitary reform in Austrian lands. This reform was closely connected with the organisation of sanitary cordon at the border of Habsburg Monarchy towards the Ottoman Empire. Institutional development of a system to prevent the spread of plague epidemics from the Ottoman Empire to Austria ran in certain way through the whole first half of the $18^{\text {th }}$ century. As early as in 1710 Vienna Court issued the first official regulatory document about the border behaviour in the case of imminent danger of plague epidemic spreading, known as "the Plague patent" (Pestpatent). ${ }^{8}$ Also, special governmental institution was formed in Vienna already in 1718, under the name Court Sanitary Commission (Sanitäts Hofkomission). ${ }^{9}$

But it was with the arrival of Gerard van Swieten that sanitary cordon gained new ground and system of quarantine was so efficiently introduced that total elimination of the disease at the area of Habsburg lands was achieved in the timeframe of only few decades. In the period up until 1763 the Austrian government was mainly occupied with major wars led against Prussia in the northern parts of the country. Because of that the creation of a dense quarantine system in the true sense began only after 1763 . Among others, special regulations have been made in Vienna to schedule the obligations of border guards who were in service at the quarantine stations. ${ }^{10}$ Special sanitary commissions were established, with headquarters throughout border region and with lazarettes, as institutions for the accommodation of patients directly related to quarantines. ${ }^{11}$ Van Swieten was main proposer of new measures in the system of structure buildings at the border and he collected and published all necessary knowledge in patent called Generale Normativum in Re Sanitatis. Empress officially implemented this patent in $1770 .{ }^{12}$

The Austrian protection system established under the guidance of the scientist from the Netherlands has proven to be very effective. Success in dealing with the plague epidemics has strengthened the Vienna court in its orientation towards further implementation of modern scientific measures in facing with the challenges of medicine and therefore helped significantly to Van Swieten in his efforts to overcome aspects of Jesuit influences still very present in education in the Habsburg lands. ${ }^{13}$ Although he alone was Catholic and in the childhood under tutelage of Jesuits, he was a loud opponent of the Order who was a dominant force in the education of all Catholic lands in Europe throughout previous two centuries. Like 


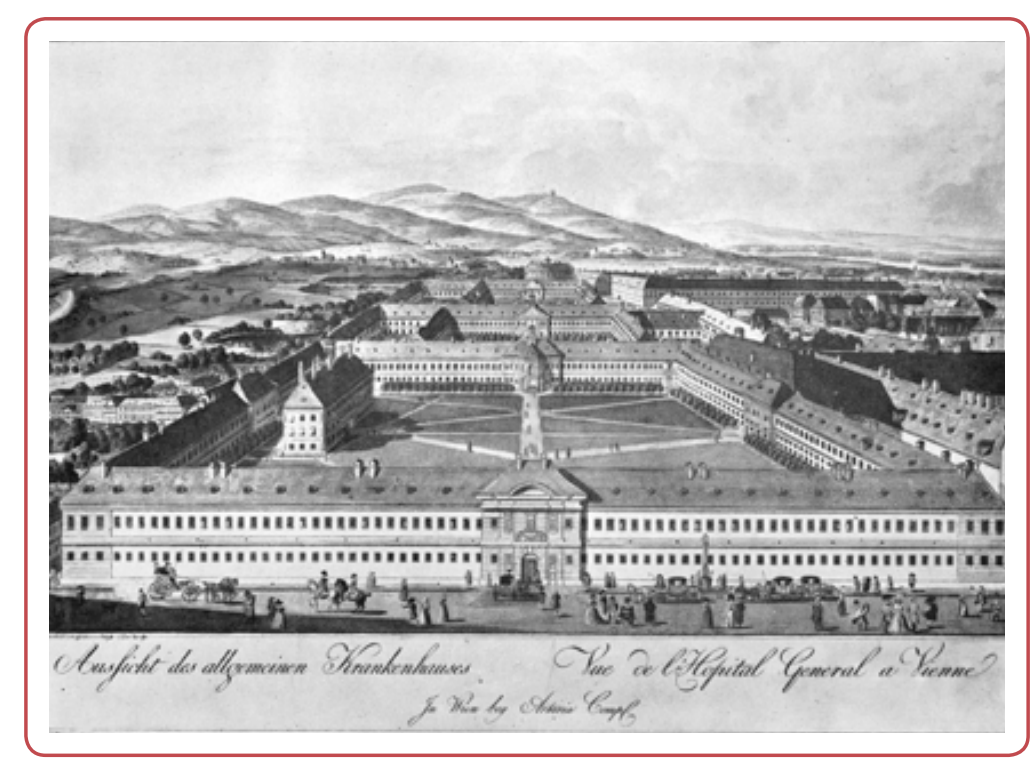

in the case of famous Austrian diplomat and later internuncio in Istanbul, Baron Peter Philipp von Herbert-Rathkeal (1735-1802), who was a member of Jesuit Order during his early years and later fierce opponent to his former guardians, ${ }^{14}$ Van Swieten was one of several personalities in Austria with Jesuit educational background who actually mostly helped in defeating the Jesuit dominance and consequently advised Empress in approach to finally suppress and expel the Society of Jesus from Austrian lands in 1767.

Already during first several years in Vienna, Gerard van Swieten pushed in very different fields with implementation of reforms, not only inside of medical science, but also in the social system in general. Structurally, for medicine it was of huge importance that he has implemented separation of medical training and administration of system of public health in 1749. In addition, from the very start in Vienna in 1745, he was entitled as librarian for Empress Maria Theresa in what at that time still was the Imperial Library. ${ }^{4}$ Position in the library and close relations with the Empress enabled his dominance in the questions regarding the censorship. He broke with the middle age practice of public burning of the books but was very strict in the sense of purging of science especially of influences that came from alchemy and superstitions. ${ }^{5}$ With this modern and direct approach he has managed to remove Jesuits from the control of censorship. Jesuit control over this institution actually enabled them to keep all aspects of science in Austrian lands inside of their sphere of power. Similar approach that was in use by Van Swieten in the world of medical sci- ence was immediately after widened to the prosecution of literature in general. He constantly insisted only on logic and rational and scientific aspects in his judgements regarding the publication of books and pamphlets.

Still, his primary concentration on medicine was unquestionable. Therefore, he mainly paved the way for further institutional development of the Medical Faculty at the University of Vienna. He has advised Empress to hastily issue patents for organisation of separate courses at the faculty. In that way he has prescribed formation of courses for chemistry, botany, surgery and, as a special innovation in Austria and direct consequence of influences by his mentor Herman Boerhaave, he has founded separate courses for clinical medicine, where the approach in treating of the patients was actually taught to students directly next to patient's bedside. ${ }^{6}$ Practice of direct teaching in hospitals was a quantum leap for medicine in Austria.

Placement of Van Swieten on the position of the director of studies was unavoidably a decision in the context of his dominant role. At the same time, young dean of the Medical Faculty Anton Störck (1731-1803) was his close collaborator and former pupil. ${ }^{4}$ Van Swieten was also mainly responsible for creating a new curriculum, where medical theories were strongly interlinked with practice. Instructions and supervisions in the curriculum have been specifically separated also for education and guidance of specific medical professions like surgeons and barbers (Figure 2). This system was quickly implemented at all medical 
institutions of Austrian lands, so what started in Vienna was very soon new reality also in Prague, Buda, Lemberg and Padua and all other universities under control of the Habsburg Monarchy. ${ }^{5}$

All mentioned merits and credits he has earned in Vienna during first several years were closely followed from the side of leading European academic institutions. It was not surprising at all that very soon he was included as member in some of most prestigious scientific academies. It was in 1749 that he was elected a Fellow of the Royal Society in London and two years later he was also elected a foreign member of the Royal Swedish Academy of Sciences in Stockholm. ${ }^{4}$ Finally, in 1754, when he was already made baron (Freiherr) by the Empress, Van Swieten was accepted as a member in the Leopoldina, German Academy of Sciences in Halle. ${ }^{5}$

\section{Fight against barbarism}

A very illustrative episode of the changing influence that Van Swieten has brought with him in Vienna was his clash with remnants of superstition, in the frame of fight against the perception of vampires and vampirism. Myths about vampires were one of the crucial points he wanted to tackle in his battle against "barbarism of ignorance" and total eradication of such kind of folklore misconceptions was his loudly proclaimed goal. It was actually very convenient for him that throughout the first half of $18^{\text {th }}$ century stories about vampires in Austria were in circulation even more than before. One of the geographic regions where the concept of vampires was predominantly concentrated was the Balkan Peninsula. ${ }^{15}$

With the victorious end of war against the Ottomans (1716-1718) and following the undersigning of Peace Treaty of Požarevac (Treaty of Passarowitz, in August 1718), Austria managed to gain significant parts of territories in Northern Serbia and also the northernmost strip of the land of Bosnia, around rivers Una and Sava. Therefore, Austrian officials have been in position to encounter a growing number of stories connected with vampirism and particularly illustrative episodes have been reported from several villages in Northern Serbia in 1725, and then again in 1732 about local robbers-hero freedom fighters (hajduks), who "came back from the dead". ${ }^{16}$ Those reports actually were a starting point for transfer of the "knowledge" about vampires to the German speaking regions and even for the beginning of "scientific" explanations about possibility of vampire existence (Die europaweit erscheinenden Berichte über die Heiducken-Vampyren von Serbien von 1725 und 1732 lösen eine Flut von 'Facharbeiten' über Vampyre aus....). ${ }^{17}$

Allegedlly strong evidence about the "vampire activity" have been in circulation in Moravia, so Empress Maria Theresa decided to send Van Swieten to the research in situ. Arriving in Moravia, to the north from the City of Brno (Brünn), in 1755 , Van Swieten carefully investigated all testimonies. ${ }^{18}$ After concluding the investigation, he made a detailed report with the title "Treatise on the Existence of Wraiths" (Abhandlung des Daseyns der Gespenster). ${ }^{17}$ This report was published more than a decade later, in German for the first time in 1768.

In his report Van Swieten concentrated elaboration strictly on the scientific ground. In the usual stories about vampires of that time main intention was always description of presence of almost "intact dead bodies" in graves. So, such bodies have been dug out from graves and beheaded or even burnt in the attempt to finally get rid of the continuous "danger". Such shape of "defence" against vampires was shocking for Van Swieten. He insisted that imperfect putrefaction was the crucial criterion that all alleged vampires had in common. From personal experiences with grave and coffin openings he recognised, a good 20 years before the discovery of oxygen, that such phenomena occur especially when the corpse was buried under particularly strong air exclusion, which actually prevented usual rate of body decomposition..$^{18}$ In his statement he underlined: "...that all the noise came from nothing else than a vain fear, a superstitious gullibility, a dark and agitated phantasy, simplicity and ignorance among that people." (...daß der ganze Lärm von nichts andern herkömme, als von einer eitlen Furcht, von einer aberglaubischen Leichtglaubigkeit, von einer dunklen und bewegten Phantasey, Einfalt und Unwissenheit bei jenem Volke.). ${ }^{17}$ Even more, Van Swieten was very willing to add some ironic remarks in his final review of the stories connected with the testimonies about development around the graves at cemeteries: "Others believed they saw or heard a dog, a calf, a pig, a calf's head. Was it then necessary for the devil to give life to a dead human body, to appear in such a dog or calf shape? There is not the slightest connection between the cause and the given effect." (Andere 
haben geglaubt, sie sehen oder hören einen Hund, ein Kalb, ein Schwein, ein Kalbskopf. Hatte denn der Teufel nöthig, einen menschlichen todten Körper lebendig zu machen, in einer solchen Hundes- oder Kalbesgestalt zu erscheinen? Es ist ja zwischen der Ursache, und der vorgegebenen Wirkung nicht die geringste Verbindung) $\cdot{ }^{17}$ Final consequence of Van Swieten's mission to Moravia was immediate ban on all activities connected with the desecration of graves, through the so called "Vampire Proclamation" (Vampir-Erlass), from March 1755. ${ }^{18}$ Myths about vampires have been efficiently exterminated from Austrian lands. Nevertheless, longstanding impact of Van Swieten in his "fight against vampires" was so strong, that even some 150 years later he was one of crucial inspirations for Irish author Bram Stoker (1847-1912) in creation of the character Abraham Van Helsing, a vampire-hunter, for his famous novel "Dracula" from $1897 .^{19}$

\section{First Vienna Medical School}

Concept of the First Vienna Medical School was rooted inside of the complete system that Van Swieten was able to set in motion. It was his personal suggestion to the court that inspired foundation of first modern clinic in Vienna in 1754. Dealing with human resources in upcoming years and decades was another testimony of Van Swieten's efficiency, for all of his choices have been among the best possible in Europe of that time. First of all, he has brought from Leiden Doctor Anton de Haen (1704-1776). De Haen studied together with Van Swieten and he was another successor of methods earlier applied by Herman Boerhaave in Leiden. ${ }^{20}$ Under the instructions of Van Swieten, De Haen was appointed as first director of clinic in Vienna placed in Bürgerspital. His approach was full triumph of Bierhaave's practical instruction "Away from the textbook, towards the patient!". With De Haen, first Vienna clinic not just became place of lecture, it grew as well into significant place of research. ${ }^{21}$

Successor of De Haen at the position of director of clinic in Vienna was Maximilian Stoll (17421787). Stoll was another close follower of medical traditions established by Boerhaave and Van Swieten. His results at the field of epidemiology have been especially remarkable. As a doctor he was one of first practitioners in keeping of daily progress records of patients and also of percussion methodology. As young physicians Leopold von Auenbrugger (1722-1809) and already mentioned
Anton Störck started their careers at the clinic as assistants in the 1750's. In upcoming decades, they had main role in further widening of initial Van Swieten's visions regarding the transformations of medicine. Von Auenbrugger was real inventor of percussion. He was the first physician ever able to understand differences in sound that arise during the tapping on the surface of the patient's chest wall at different points. Therefore, he was in position to fairly assess the status of texture in underlying organs and tissues deeper in body. His research was published in 1761 under the title Inventum novum ex percussione thoracis humani ut signo abstrusos interni pectoris morbos detegendi. ${ }^{22}$

Anton Störck was indeed a sublimation of First Vienna Medical School. He came to Vienna from the German region of Baden-Württemberg as an orphan. Since 1752 he studied medicine under personal guidance of Van Swieten. Under his mentorship Störck was promoted in 1757. Next years have been very fruitful for Störck. His university career was crowned by his appointment as dean of the Medical Faculty already in 1766 and as Rector magnificus of the Vienna University in 1768. Maria Theresa chose him as the treating doctor when she contracted smallpox in 1767. After a successful healing, she appointed Störck as her personal physician and he was made a Baron in $1775 .^{22}$ Career of Anton Störck was most similar to the fast rising of Van Swieten few decades earlier. Cooperation with his famous mentor was also of huge significance in the field of experimental pharmacology. Störck made first breakthrough in the clinical research of various healing herbs. In this frame he has also established clinical trials in modern medicine, for he experimented with the dosage of quantities, initially on animals, and later by a personal trial. ${ }^{21}$

Development of pharmacology in Vienna was closely bound with old Van Swieten's connection with pharmacy and botany. Van Swieten founded a botanical garden in Vienna and a chemical laboratory next to it. He also introduced clinical instruction in the field of appliance of new methods of pharmacy and chemistry. In this frame of utter importance was another research initiative started by the Dutch doctor. ${ }^{4}$ Nikolaus Joseph von Jacquin (1727-1817) was yet another pupil from Leiden brought to Vienna by Van Swieten. In Vienna he attended lectures by the famous Dutch professor. For his inclination towards botany and 


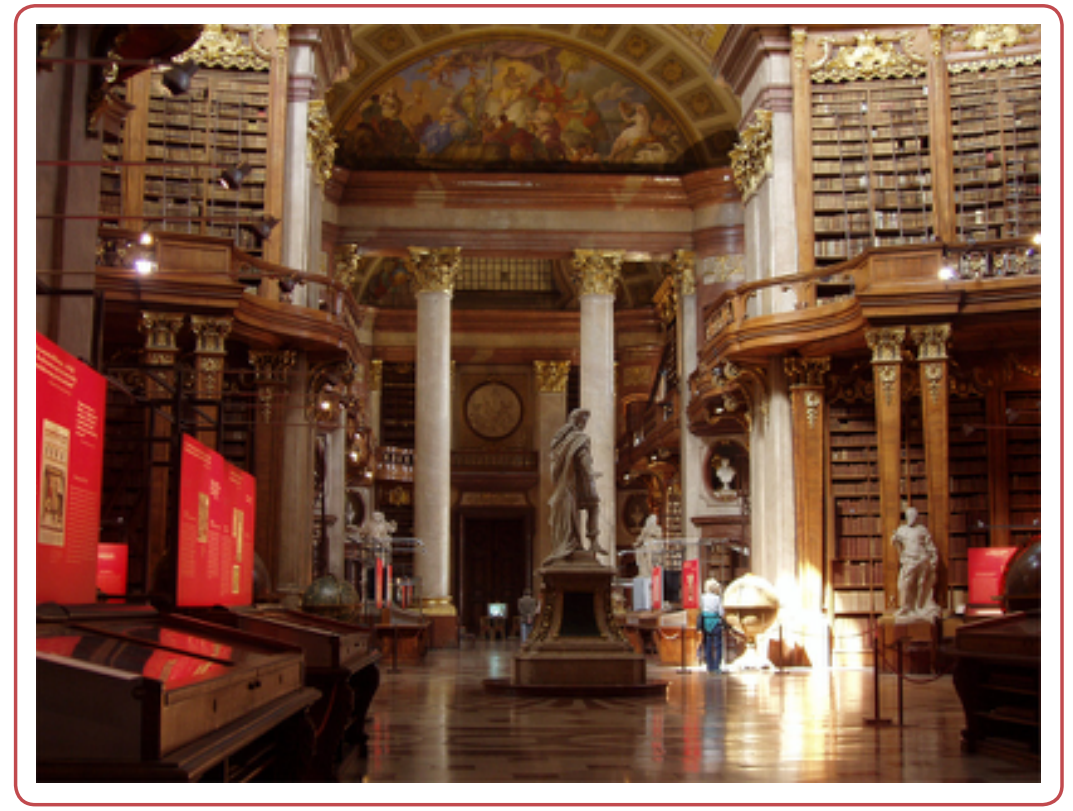

Figure 3: Austrian National Library

chemistry was exceptional, he was chosen by Van Swieten to lead the first Austrian expedition to the West Indies and Central America with the goal to collect plants for the Schönbrunn Palace. ${ }^{23}$ Between 1755 and 1759 Jacquin amassed a very large collection of animal, plant and mineral samples and after return of those specimens to Vienna Van Swieten was in position to further organise botanic and pharmaceutical studies. As further reward, in 1768, Jacquin was appointed Professor of Botany and Chemistry at the University of Vienna and he also became director of the

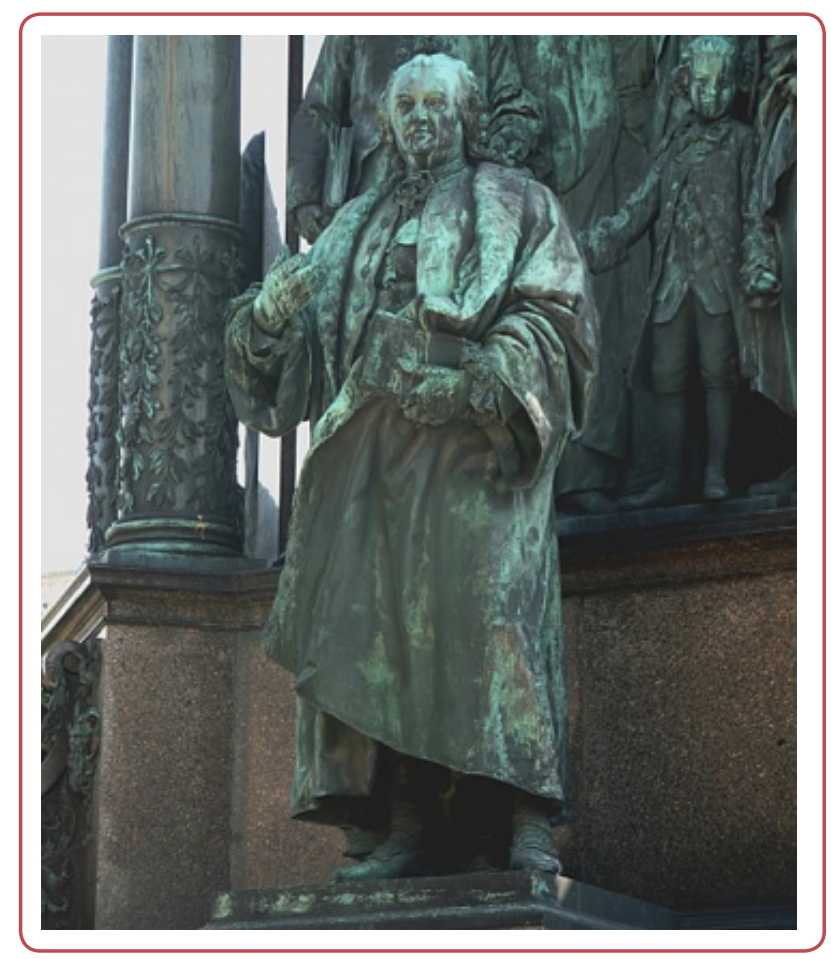

Figure 4: Statue of Gerard van Swieten in Vienna botanical garden within the University. ${ }^{5}$

Expedition led by Jacquin was forerunner of wave of expeditions that Austria was about to organise in upcoming decades towards Americas, Africa, Asia and Pacific, both in the context of economy and trade and in intention of further bolstering of science, like in the case of botanical expedition led by Franz Joseph Märter (1753-1827), towards southern parts of newly formed United States of America, Caribbean Islands, northern parts of South America, South Africa and Madagascar, between 1783 and $1788{ }^{23}$

Numerous breakthroughs made by Vienna Medical School during 1780's were not led and followed anymore by Gerard van Swieten. He died in 1772. His son Gottfried at that time already became famous on his own, primarily as an Austrian diplomat. He was posted in the embassies to Brussels, Paris and Warsaw, but his mission as ambassador in Berlin (1770-77), at the court of Frederick the Great, King of Prussia, was most important. Like his father, Gottfried van Swieten also held position of the Prefect of the Imperial Library (Figure 3). During the decade of the rule of Joseph II (1780-1790), younger Van Swieten was at the height of his political power, in the positions of Councillor of State and Director of the State Education Commission and also later on as Director of a Censorship Commission, which was another footprint his father already made decades earlier. Gottfried van Swieten was also known as supporter and patron of some famous classical composers, like Mozart, Haydn and young Ludwig van Beethoven. ${ }^{5}$ In that way the contribution of the Van Swieten family to the development of Vienna 
in the second half of 18th century was even more rounded (Figure 4).

Unfortunately, some aspects of contributions of the First Vienna Medical School have been long neglected in the general history of medicine. It is only in last several decades that growing research is showing vast affluence of this system and institutions that were produced in the course of its development. Rightly so, for foundations that were set up by Gerard van Swieten in Vienna, in the 18th century, are pretty much foundations of modern system in medical science, especially in the field od clinical development and pharmaceutical research.

\section{Conclusion}

Activities of Gerard van Swieten in Vienna during the era 1745-1772 are hard testimony about possibilities of one person to implement dramatic set of reforms in the field of science in the case when that particular person is in possess of superb foundation in educational and scientific frame. Coming from Leiden, Netherlands, with outstanding tradition of medical science, Van Swieten embodied all the liberal qualities developed in most progressive part of Europe during previous century. Influences of Herman Boerhaave, as crucial carrier of new systematic approach in Leiden medical practice have been deeply rooted in Van Swieten throughout all decades of his transformative attitude in Vienna.

Van Swieten was lucky that he has arrived in Vienna in situation where structures of Habsburg dynasty were much more flexible and readier to open the field od medicine and science in general to modern influx of liberal tendencies. Decadent baroque heritage of previous decades of rule of Charles VI, father of Empress Maria Theresa, was fairly quickly left behind and foundations for First Vienna Medical School were strong in rolling already in the 1750's. But it was the spirit of Van Swieten with his general modesty and complete readiness for cooperation that enabled such huge step forward and almost instant transformation of Vienna into one of the leading medical centers.

\section{Acknowledgements}

None.

\section{Conflict of interest}

None.

\section{References}

1. Israel JI. The Dutch Republic. Its rise, greatness, and fall 1477-1806. Oxford-New York: Clarendon Press; 1998.

2. Schama S. The embarrassment of riches: an interpretation of Dutch culture in the Golden Age. New York: Alfred A. Knopf; 1987.

3. Bronza B. Austrian trade towards Ottoman Empire and Asia in 18th century. Istraživanja - J Hist Res 2016;27:139-52. DOI: 10.19090/i.2016.27.139-152.

4. van der Korst JK. Een dokter van formaat: Gerard van Swieten, lijfarts van keizerin Maria Theresia [A great doctor: Gerard van Swieten, personal physician to Empress Maria Theresa]. Amsterdam: Uitgeverij Bert Bakker; 2003. Dutch.

5. Lesky E, Wandruszka A, eds. Gerard van Swieten und seine Zeit [Gerard van Swieten and his time]. Internationales Symposium veranstaltet von der Universität Wien im Institut für Geschichte der Medizin 8.-10. Mai 1972. Wien: Hermann Böhlaus Nachfolger; 1973. German.

6. Frederiks JAM. Gerard van Swieten (1700-1772). Een beroemde en trouwe leerling van Boerhaave) [Gerard van Swieten (1700-1772). A famous and loyal student of Boerhaave]. Gewina 2000; 23: p. 123-132. (Dutch).

7. Doria JL. Antonio Ribeiro Sanches. A Portuguese doctor in 18th century Europe. Vesalius, VII, 1; 2001. p. 27-35.

8. Panzac D. Quarantaines et lazarets. L'Europe et la peste d'Orient (XVIIe-XXe siècles) [Quarantine and Lazarets. Europe and the Oriental plague (17th-20th Centuries)], Aix-en-Provence; 1986. French.

9. Lesky E. Die österreichische Pestfront an der k.k. Militärgrenze [Austrian front against plague on military border], Saeculum 8. Wien; 1957. p. 82-105. German.

10. Österreichisches Staatsarchiv, Abteilung Haus-, Hofund Staatsarchiv (further on: HHStA), Staatskanzlei, Provinzen, Illyrien, Kart. 1, Fasz. ad 1753 (1-192), Fol. 118-121.

11. HHStA, Staatenabteilungen, Illyrico-Serbica, Kart. 1: 1611-1738, Fasz. Illyrico-Serbica K1/Konv. B, 1-431, Fol. 35-39.

12. Bronza B. Austrian measures for prevention and control of the plague epidemic along the border with the Ottoman Empire during the 18th Century. Scr Med 2019;50(4):177-84. 
13. Bramanti B, Dean KR, Walløe L, Chr. Stenseth N. The Third Plague Pandemic in Europe. Proc R Soc B 2019;286:20182429. DOI: 10.1098/rspb.2018.2429.

14. Bronza B. Austrian diplomats from the Vienna Oriental Academy on the Balkan peninsula during the second half of the eighteenth century. In: Baramova M, Mitev P, Parvev I, Racheva V, eds. Power and influence in South-Eastern Europe, 16th-19th century. Berlin: LIT Verlag; 2013. p. 329-338. DOI: 10.15463/ rec.1189731762.

15. Sechel TD. The Emergence of the medical profession in Transylvania (1770-1848). In: Karady V, Török BZ, eds. Cultural dimensions of elite formation in Transylvania (1770-1950). Cluj-Napoca: CRDE; 2008. p. 95-114.

16. Klaniczay G. Gerard van Swieten und die Anfänge des Kampfes gegen Aberglauben in der Habsburg-Monarchie [Gerard van Swieten and the beginnings of the fight against superstition in the Habsburg Monarchy]. Acta Hist Acad Sci Hung 1988;34(2/3): 225-47. German.

17. Mayer AU. Abhandlung über das Daseyn der Gespenster, nebst einem Anhange vom Vampyrismus [Treatise on the existence of wraiths, with an appendix on vampyrism]. Augsburg; 1768. German.

18. D'Elvert C. Das Zauber- und Hexenwesen, dann der Glauben an Vampyre in Mähren und Oesterr. Schlesien
[The magic and witchcraft, then the belief in vampires in Moravia and Austrian Silesia]. In: D'Elvert C, ed. Schriften der historisch-statistischen Sektion der k. k. mähr.-schles. Gesellschaft des Ackerbaues, der Natur und Landeskunde. XII. Bd. Brünn; 1859. German.

19. Windgassen M, Hartwig S. Historischer "Van Helsing“. Gerard van Swietens Kampf gegen den Aberglauben [Historical "Van Helsing". Gerard van Swieten's fight against superstition]. Rechtsmedizin 2017;27:497-9. German.

20. Bernard PP. The Limits of absolutism: Joseph II and the Allgemeines Krankenhaus. Eighteenth-Century Studies 1975;9(2):193-215.

21. Tragl KH. Chronik der Wiener Krankenanstalten [Chronicle of the Vienna hospitals]. Wien-Köln-Weimar: Böhlau; 2007. German.

22. Lesky E. Die Wiener Medizinische Schule im 19. Jahrhundert [The Vienna Medical School in the 19th century]. Graz-Köln: Böhlau, 1978. German.

23. Klemun M, Hühnel H. Nikolaus Joseph Jacquin (17271817) - ein Naturforscher (er)findet sich [Nikolaus Joseph Jacquin (1727-1817) - a naturalist finds himself]. Wien: Vienna University Press; 2017. German. 